\title{
Marginal Land or Marginal People? Analysing Patterns and Processes of Large-Scale Land Acquisitions in South-East Asia
}

\author{
Peter Messerli, Amaury Peeters, Oliver Schoenweger, Vong Nanhthavong, \\ and Andreas Heinimann
}

\begin{abstract}
This chapter aims to overcome the gap existing between case study research, which typically provides qualitative and process-based insights, and national or global inventories that typically offer spatially explicit and quantitative analysis of broader patterns, and thus to present adequate evidence for policymaking regarding large-scale land acquisitions. Therefore, the chapter links spatial patterns of land acquisitions to underlying implementation processes of land allocation. Methodologically linking the described patterns and processes proved difficult, but we have identified indicators that could be added to inventories and monitoring systems to make linkage possible. Combining complementary approaches in this way may help to determine where policy space exists for more sustainable governance of land acquisitions, both geographically and with regard to processes of agrarian transitions. Our spatial analysis revealed two general patterns: (i) relatively large forestry-related acquisitions that target forested landscapes and often interfere with semi-subsistence farming systems; and (ii) smaller agriculture-related acquisitions that often target existing cropland and also interfere with semi-subsistence systems. Furthermore, our meta-analysis of land acquisition implementation processes shows that authoritarian, top-down processes dominate. Initially, the demands of powerful regional and domestic investors tend to override socio-ecological variables, local actors' interests, and land governance mechanisms. As available land grows scarce, however, and local actors gain experience dealing with land acquisitions, it appears that land investments begin to fail or give way to more inclusive, bottom-up investment models.
\end{abstract}

A growing body of scientific evidence on large-scale land acquisitions (LSLAs) is helping to inform the heated debate regarding this rapidly unfolding

(C) Graduate Institute of International and Development Studies, 2016 | DOI 10.1163/9789004304758_007 This is an open access chapter distributed under the terms of the Creative Commons Attribution- 
phenomenon. Some researchers-particularly those using qualitative, indepth case studies - have examined land-acquisition processes within the dynamics of agrarian change and larger political-economic shifts. Other researchers have striven to establish quantitative inventories of LSLAs to improve our understanding of the scale and dimensions of land acquisitions at the national (Görgen et al., 2009; Schönweger et al., 2012; Üllenberg, 2009), regional (Friis and Reenberg, 2010), or global level (Anseeuw et al., 2012; Cotula, 2012; Deininger and Byerlee, 2011). Based on such inventories, the World Bank has deemed 445 million hectares (ha) of land worldwide to be 'marginal land' that could benefit from agricultural investments because it is not forested or under protection and has population densities below 25 people per $\mathrm{km}^{2}$ (Deininger and Byerlee, 2011).

Both qualitative case-based approaches and quantitative inventory-based approaches have persistently met with difficulties and criticism when it comes to guiding policy on land investments. While case studies focussing on specific local contexts are good at capturing processes and interactions, they have limited geographical validity and are typically ill-suited to generalising and informing policy at higher spatial levels (Anseeuw et al., 2012; Messerli et al., 2013). By contrast, regional and global inventories based on quantitative approaches are useful for making large comparisons, but frequently lack insight into processes and fail to account for variety and differentiation; they have also been criticised for relying on faulty or incomplete data sources and for lacking verification on the ground (Edelman, 2013; Oya, 2013). Similarly, hasty assessments about unused or underused 'marginal' land have been consistently refuted by intensive case study research (Borras Jr. et al., 2011; Dwyer, 2013; Nalepa and Bauer, 2012). This research has shown that land targeted by international land deals is often not idle at all, but rather is subject to claims and is used by people who are increasingly being marginalised by processes of globalization.

From a policy perspective, it remains a point of dispute whether or to what extent LSLAs target marginal land and/or create marginalised populations. Overall, the policy-related evidence provided by researchers appears ambiguous and often contradictory. Because of this, recent proposals have recommended bringing together country-level and case-based research approaches, taking advantage of conceptual and methodological complementarities (Messerli et al., 2013; Scoones et al., 2013). Such a research agenda would aim at linking patterns of quantitative, place-based (spatially referenced) assessments of LSLAs to insights from processes-based, frequently qualitative case studies.

Supplying useful scientific evidence for decision-making and policymaking has also proven difficult in South-East Asia. Here, LSLAs have emerged mainly 
as a regional phenomenon, contrasting somewhat with the 'land rush' in Africa and Latin America where global drivers are seen as especially important (Anseeuw et al., 2012). Such acquisitions reflect a broader picture of agricultural and societal transformation, characterised by a rapid shift away from rural subsistence-oriented agriculture in favour of more urbanised societies and industrialised, market-based forms of land use. Often termed 'agrarian transition' (De Koninck, 2004; Rigg, 2006), this transformation comprises many simultaneously occurring processes such as agricultural intensification and territorial expansion, market-based economic integration, rural-urban migration, new forms of regulations governing agricultural production, and urbanisation. None of these processes necessarily follow a linear path and their pace differs from place to place. Rural transformation processes vary considerably across the region and across different scales, making it difficult to properly conceptualise and understand changes in the Asian countryside as they occur (Rigg, 2005). LSLAs have led to highly dissimilar outcomes from one place to another. Thus, using single case studies or locally obtained empirical results to formulate regional or national policy is highly problematic.

This paper focuses on land investments in Laos and Cambodia. The land resources in both countries are under significant pressure from LSLAS, especially as a result of foreign direct investment by neighbouring riparian countries. Our overall goal is to identify distinct spatio-temporal patterns of LSLAS across the two countries and to attempt to link them to recurrent or archetypal processes of implementation of land deals from concession granting to the final allocation of land. This encompasses two primary objectives: (1) methodologically, we aim to explore and illustrate how quantitative, place-based (spatial) analysis of land investments can be linked to process-based, qualitative studies; (2) as regards content, we aim to improve-based on better methodology — the generalisation of evidence on LSLAs for policymaking and decision-making.

The paper is structured as follows. In section 2, we describe our methodology and the results of analysing spatial patterns of LSLAs based on countrylevel inventories. Here, we focus on the origin of the investors, on crop types, and on geographical target contexts (including social and ecological characteristics). In section 3, we describe how we used a meta-analysis of case studies to identify key factors of LSLA implementation processes and recurrent linkages between these key factors. Based on these recurrent linkages, we propose four so-called archetypes of land acquisitions as the basis for a working typology of implementation processes. Finally, in section 4 we discuss whether and to what extent spatial patterns of land deals can be related to archetypes of 
implementation processes in order to improve the validity and generalisation of research results for policymaking purposes.

\section{Analysing Spatial Patterns of LSLAs in Laos and Cambodia}

\section{1}

\section{Materials and Methods}

In both Laos and Cambodia, national databases of LSLAs have been gradually built using different information sources furnished by different agencies and initiatives. In Laos, the bulk of data was collected through an inventory of land concessions and leases (from the local level to the national level) conducted between 2007 and 2010, with additional updates and data cleaning occurring in 2012 (Schönweger et al., 2012). Only $5^{0}$ per cent of the granted deals collected in this inventory were spatially referenced. For the purpose of our analysis, only the spatially referenced deals were used, encompassing 597,6oo ha of land (out of 1.1 million ha, in total, of granted land concessions and leases).

The Cambodian database was drawn together from a variety of information sources. It includes official data gathered by Open Development Cambodia (ODC, 2013); data from LICADHO (2013); data from NGO Forum (2012); and data from the Ministry of Agriculture, Forestry and Fisheries of Cambodia (2012); as well as our own field data. The resulting database combines data on land concessions (with spatial-reference data) comprising 490 deals that cover 4.5 million ha; the most recent updates and data cleaning took place in September 2013.

Using these unique data sets, we conducted a descriptive analysis looking at investors' country of origin, the intended purpose of the deal (by sub-sector), and the date of approval for each land deal. To gain some initial insights into the national-level characteristics of land acquisitions in Laos and Cambodia, we compared the geo-referenced land-deal data with other important spatially referenced country-level data sets, in particular those on poverty incidence, accessibility to provincial capitals, and land cover. Because the national land cover data sets for Laos and Cambodia were not comparable (due to differing methods and classifications), globally available data were used from the GlobCover 2009 land classification (Arino, 2010). We calculated the accessibility of provincial capitals (i.e. travel time in minutes) with cost-distance algorithms in ArcGis 10, using national road data sets, digital elevation models, land cover data, and main rivers as inputs (Messerli et al., 2008). For Laos, we used village-level poverty data-from Epprecht et al. (2008) - that were calculated using small-area estimation based on figures from the 2005 Lao Population and Housing Census and the 2003 Lao Expenditure and 
Consumption Survey (LECS) III. For Cambodia, poverty measures were derived from the Identification of Poor Households Programme data set (Kingdom of Cambodia, 2012) and the Commune Database (NCCD, 2012) for 2008-2010.

\subsection{Spatial Patterns of LSLAS in Laos and Cambodia}

2.2.1 Dimensions and Scale of LSLAS

An openness to private investment in the form of land concessions has been present in the economic development policies of both countries for many years. In Cambodia, a new legal framework was adopted for land investment in 2001; the same occurred in Laos in 2003. In both countries, a series of additional laws and decrees have reinforced and concretised the trend towards private land investment (NAoL, 2004; GoL 2008; RGC, 2005). Investors' responses have not been slow in coming, giving rise to a veritable 'land rush' in both countries. The countries' respective governments have also made private investments in land an explicit part of their official development strategies and policies. But the growing scale and pace of land concessions have proven highly challenging to govern properly, sparking criticism both locally and internationally. The total number of concessions granted in Laos increased fiftyfold between 2000 and 2009, rising steeply after 2005 (Figure 6.1). In Cambodia, there was also a

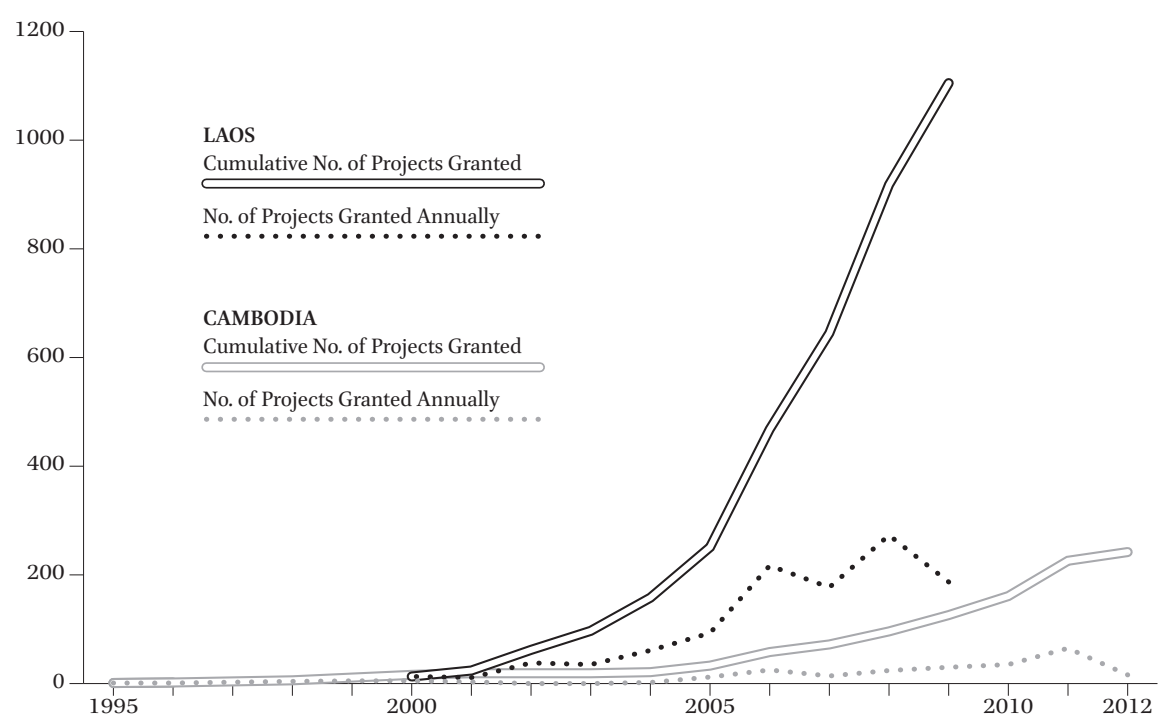

FIGURE 6.1 Trends of land concessions granted in Cambodia and Laos.

Note: Figures for Cambodia do not include mining concessions, as no information about the granting date of mining concessions was available.

SOURCE: AUTHORS. 
sharp increase in land deals after 2005. The most impressive observation, however, remains that—starting in 2000 - it took only eight years to double the area granted to investors, from 0.5 million ha in 2000 to over 1 million ha in 2008 , and only another four years to double it again, reaching over 2 million hectares in 2012.

Despite the announcement of moratoriums on new land concessions in Laos (2007, 2009, and 2012) and Cambodia (2012), these deals play a major role in the economies of each country and will continue to do so based on the sheer size of existing deals. Today, Laos has already granted approximately 2,640 land concessions for 1.1 million ha (Schönweger et al., 2012), while Cambodia has granted about 490 concessions for 4.5 million ha, including mining concessions. Notably, land granted as concessions or leases constitutes around 5 per cent of the territory of Laos and around 25 per cent of the territory of Cambodia.

\subsubsection{Spatial Distribution of LSLAS}

While land investments are spread throughout the two countries, there are regions where they are more clustered and more highly concentrated in terms of land area used (Figure 6.2): in the north of Laos, in the north and the northeast of Cambodia, and also in the south-western region of Cambodia. With regard to the origin of investors, domestic investments play an important role in terms of the absolute number of deals in both countries. These domestic investments are distributed in a similar manner to foreign investments across each country.

\subsubsection{Investors and Main Sub-Sectors Behind LSLAS}

While in Cambodia domestic deals account for almost 50 per cent of the entire land area granted, in Laos they account for less than 15 per cent (Table 6.1). Consequently, domestic investors in Laos have much smaller deals (by area) on average. Non-domestic investments are dominated in both contexts by the following neighbouring countries: China, Vietnam, and Thailand. The proximity of areas to country of origin of the investors who invest in those areas partly explains the distribution of these regional investments (Figure 6.2). Investments from foreign countries outside the region, aggregated here under the category 'international', only represent small shares (by area and number) of the remaining concessions (Table 6.1).

In terms of the intended purpose of deals, the forestry sub-sector-including all forms of tree crops (mainly rubber, eucalyptus, and teak) —outweighs the agricultural sub-sector in both countries based on land area used: the figures are $15,157 \mathrm{~km}^{2}$ (forestry) versus $2,813 \mathrm{~km}^{2}$ (agriculture) in Cambodia; and $2,878 \mathrm{~km}^{2}$ (forestry) versus $834 \mathrm{~km}^{2}$ (agriculture) in Laos. Again, regional investors from neighbouring countries are the main source of forestry-related 


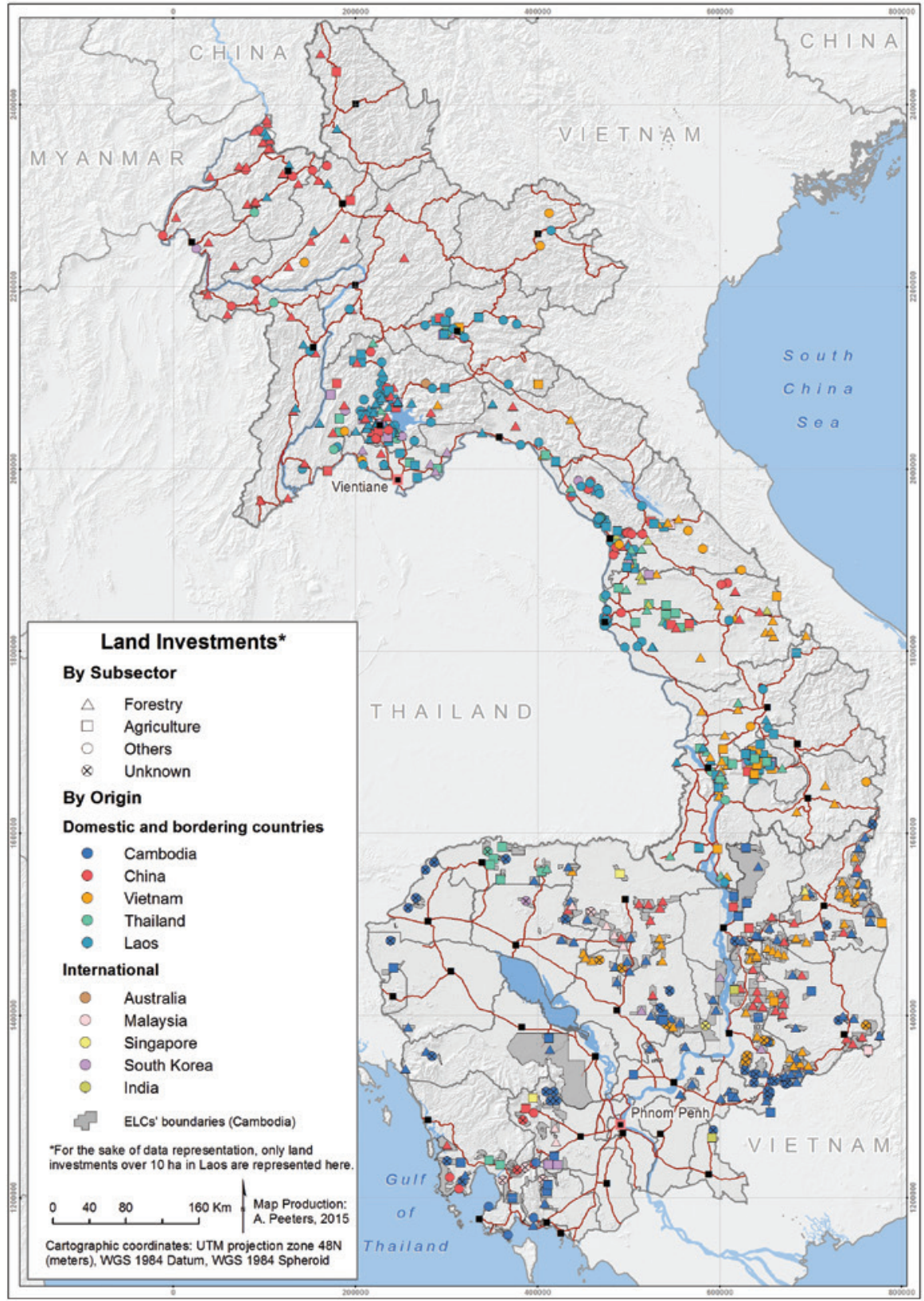

FIGURE 6.2 Investment project locations in Laos (above) and Cambodia (below) by investors' countries of origin and by subsectors.

SOURCE: COMPILED BASED ON SCHÖNWEGER ET AL. (2012), ODC (2013), LICADHO (2013), NGO FORUM (2012), AND OUR OWN DATA COLLECTION. 


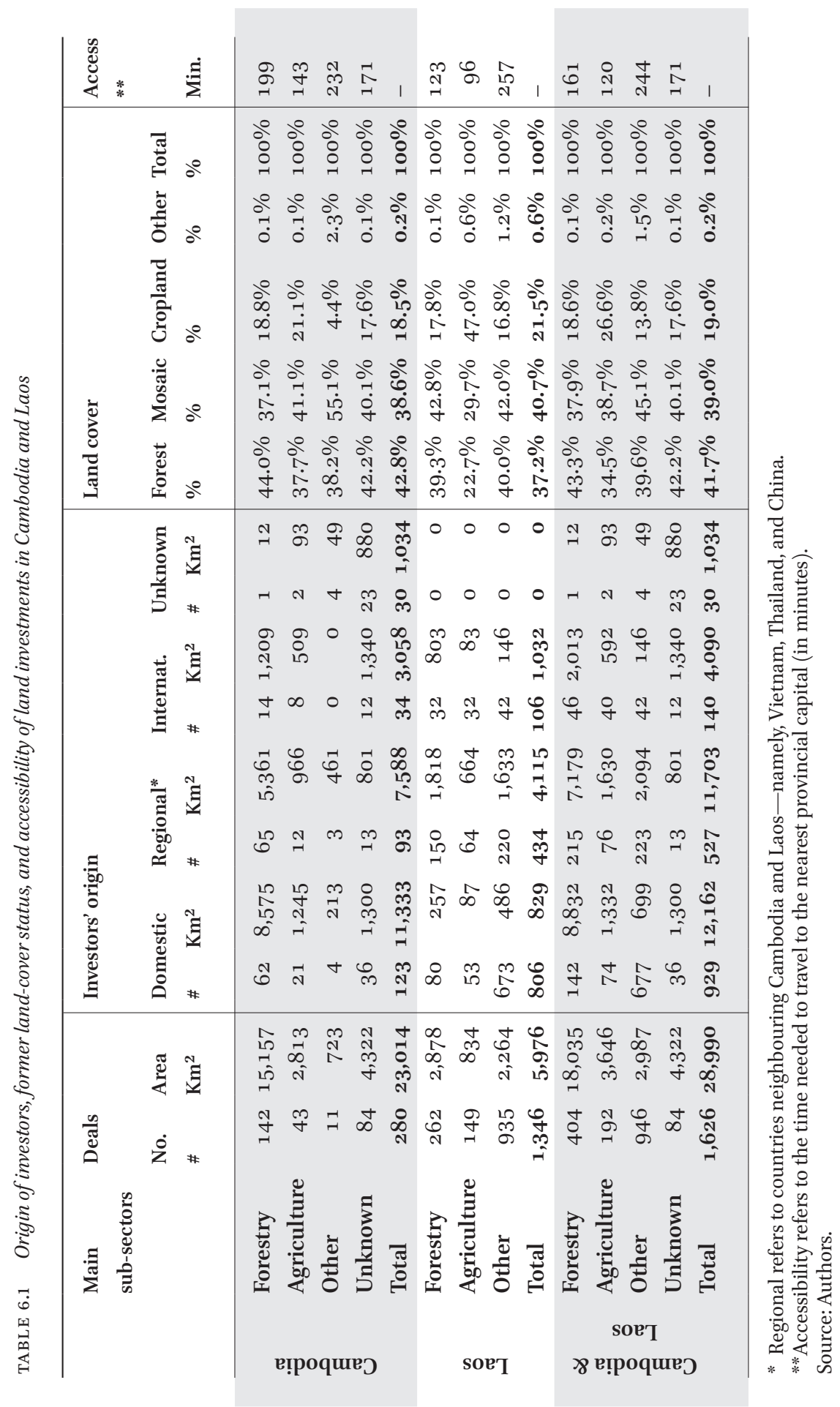


land deals in both countries taken together (53 per cent of deals), with domestic investors also being very important in Cambodia (44 per cent of deals). International investors hold only 11 per cent of all forestry concessions in both countries combined. Agriculture-related land deals are generally smaller than forestry-related land deals. Agriculture-related investments are dominated by regional (40 per cent of deals) and domestic stakeholders (39 per cent of deals) in Laos and Cambodia combined; international investors account for another 21 per cent of agriculture-related deals. It is also important to note the significance of the mining sector in Laos, as it accounts for the biggest share of land (92 per cent) among the sub-sectors classified under 'Other' for that country (Table 6.1).

\subsubsection{Geographic Contexts of Land Acquisitions at the National Level}

Overlaying our map of land deals with earlier land cover data revealed some interesting spatial patterns. Overall, land concessions are mainly granted in forested landscapes ( 42 per cent) and in landscape mosaics of forest, shrubland, and grassland (39 per cent); in Laos, such landscape mosaics have historically been the site of small-scale (mainly shifting) cultivation. Other general patterns emerging in both countries are that forestry-related concessions (e.g. tree plantations) tend to be granted in forested landscapes, while deals with an agricultural focus tend to be granted in landscapes of existing cropland. In Laos, agriculture-related concessions are twice as likely to be granted in cropland landscapes than in other types of landscapes.

Moreover, our spatial analysis reveals that the vast majority of investments are located in relatively easily accessible areas. Concessions in agriculture are the closest to provincial capitals in both countries, with an average travel time of two hours. Forestry concessions come next with an average travel time of two hours and 41 minutes to provincial capitals. Finally, concessions in other sub-sectors average over four hours of travel time - this especially reflects the importance of mining concessions in Laos, which must be situated where mineral deposits are located, of course, regardless of how remote that situation is. In Laos, land concessions tend to be more accessible than in Cambodia. Nevertheless, the main investors (domestic, Chinese, and Vietnamese) also run projects in very remote areas of both countries.

2.2.5 Summarising Patterns of Forestry- and Agriculture-Related LSLAS Laos and Cambodia have both experienced a sharp increase in LSLAs over the past decade, corresponding to a fiftyfold increase in the number of land deals in Laos and a fourfold increase in the area granted in Cambodia. The land acquisitions in Laos are smaller in size but greater in number, and in Cambodia fewer but larger. Our analysis of the geography of LSLAs in both countries 
revealed some key commonalities and differences. Aware of the risks of oversimplification, we nevertheless identified and defined the following general patterns and socio-ecological contexts of LSLAs.

First, forestry is the most important concession-related sub-sector in Cambodia and Laos based on the amount of land involved. Investors from neighbouring countries-especially Vietnam and China — play a bigger role in these forestry-related concessions than do international investors from outside the region. In Cambodia, domestic investors also play a key role in this subsector. Forestry-related concessions are typically granted for large, contiguous plots of land, often relatively close to borders of riparian countries. In most cases, these plots are located in landscapes previously classified as 'forest'; this suggests that investors may also see opportunities to extract value from timber obtained when clearing and preparing investment plots for their 'intended purpose'. In Laos, the areas where forestry concessions are located exhibit the highest poverty rates of all areas affected by LSLAs, while in Cambodia, forestry deals are in average below the national mean but concern less poor areas compared to agricultural deals. The agrarian systems affected are partly subsistence farming systems but more often semi-subsistence systems because their relatively good accessibility enables farmers to diversify their activities to include growing commercial crops or earning off-farm income.

Second, agriculture is the next most important concession-related subsector. Domestic and regional investors both play an important role in this sub-sector. Agricultural concessions are typically smaller in size than forestry concessions but are somewhat more accessible. In Laos, they tend to occur in areas displaying lower poverty incidence. Though some agricultural concessions target areas classified as forests, they more frequently target existing croplands and thus affect populations practicing lifestyles of semi-subsistence, commercial agriculture, and/or off-farm activities.

After identifying these general patterns and socio-ecological contexts of land acquisitions, we sought to distinguish the different types of implementation processes that steer such acquisitions. We defined implementation processes as encompassing all phases, from the initial negotiation of a land concession to the final allocation of land in specific socio-ecological contexts. Our processbased analyses comprised three steps: (i) conducting case studies on different types of LSLAS in order to understand the actors, activities, and institutions that guide the implementation of land deals; (ii) conducting a meta-analysis of these case studies in which we identified common key factors and analysed 
their role in the implementation process; (iii) pinpointing and examining recurrent linkages between the key factors in an effort to distinguish archetypes of LSLA implementation processes as part of a broader typology. The following section describes each of these steps. While it provides a detailed account of the specific set of methods used and the results obtained, the case studies are initially described only briefly (number and type), as we wish to focus more attention on how they were used in our meta-analysis.

\subsection{Case Studies on Implementation Processes of LSLAS}

Our meta-analysis draws on 15 case studies primarily conducted as Master's thesis projects between 2011 and 2013 in Laos and Cambodia, as part of a broader research project (Michel, 2013; Sommer, 2013; Zurflueh, 2013). Each case study focused on a separate company that sought to acquire land in order to invest in a specific crop. The case studies were designed to improve our understanding of land-deal implementation processes over time (from negotiations to allocation of land) and across different scales, whether spatial or administrative. Each was conceptually based on a human actor model that differentiates the activities and agency of actors from the dynamic conditions of action and the intuitions in which actions are embedded (Wiesmann et al., 2011). The case studies were selected based on national inventories of land investments in Cambodia (LICADHO, 2013; ODC, 2013) and Laos (Schönweger et al., 2012) using factors such as crop type, investor origin, and size of concession area as sample criteria. A total of 22 case studies in seven Lao provinces and 8 case studies in two Cambodian provinces were conducted; of these, 15 were included in our meta-analysis (see Table 6.2).

\subsection{Meta-Analysis of Case Studies on LSLA Implementation Processes \\ 3.2.1 Identification of Key Factors}

In general terms, our meta-analysis corresponds to an a posteriori comparison of already published case studies (Lambin and Geist, 2006). However, our approach differs from many meta-analyses in land science that investigate land use decision-making based on comparison of predefined direct or indirect drivers. Because each of our case studies followed a conceptual design based on a human actor model (Wiesmann et al., 2011), they revealed numerous interrelations between actors, actions, conditions of actions, and institutions. In order to maintain this broad range of important variables and also to focus our analysis on the most relevant, recurrent interactions, we performed a sensitivity analysis for each case study as a basis for our meta-analysis. The sensitivity model for the analysis of dynamic systems was initially developed by Vester and Hesler (1987), and then further adapted for the analysis of 
TABLE 6.2 Case studies used for the meta-analysis of LSLA implementation processes

\begin{tabular}{|c|c|c|c|c|}
\hline Crop & $\begin{array}{l}\text { Investors' } \\
\text { origin }\end{array}$ & Company & Location (Province) & $\begin{array}{l}\text { Area granted } \\
\text { (ha) }\end{array}$ \\
\hline \multirow[t]{9}{*}{ Rubber } & \multirow[t]{4}{*}{ China } & Ruifeng & Luangnamtha & 10,000 \\
\hline & & Lilieng & Vientiane Prov. & 2,500 \\
\hline & & Rongxieng & Savannakhet & 2,407 \\
\hline & & Guangda & Savannakhet & 1,800 \\
\hline & \multirow[t]{4}{*}{ Vietnam } & Daklak & Attapeu, Champasack & 10,000 \\
\hline & & Hoang Anh Ya Lay & Attapeu & 10,000 \\
\hline & & Ho Chi Minh Youth & Attapeu, Champasack & 6,00o \\
\hline & & $\begin{array}{l}\text { Viet Lao Rubber } \\
\text { Joint Stock }\end{array}$ & Champasack & 10,000 \\
\hline & Thailand & Lao Thai Hua & Vientiane Prov. & 30,000 \\
\hline Eucalyptus \& & China & Sunpaper & Savannakhet & 39,000 \\
\hline \multirow[t]{2}{*}{ Acacia } & India & Birla Lao & $\begin{array}{l}\text { Khammuane, } \\
\text { Savannakhet }\end{array}$ & $5^{0,000}$ \\
\hline & Japan & Oji Lao & Khammuane & 50,000 \\
\hline \multirow[t]{2}{*}{ Coffee } & Singapore & Outspan & Champasack & 2,900 \\
\hline & Thailand & Paksong Highland & Champasack & 3,100 \\
\hline Sugar cane & Thailand & Mitr Lao & Savannakhet & 10,000 \\
\hline
\end{tabular}

SOURCE: AUTHORS.

socio-ecological systems by Messerli (2000). It initially requires researchers to define a set of key factors that: (i) are representative of the social, political, economic, and environmental dimensions of the system; and (ii) capture key interactions between these factors occurring in the system.

This narrowing down of key factors was discussed and carried out together with the researchers who conducted the original case studies. We defined three general domains considered to be important mutual conditions of action in the LSLA implementation process: the domain of land investment, the domain of land governance, and the domain of the socio-ecological context. For each of these domains, we then chose eight key factors covering relevant components of the human actor model and corresponding to the criteria mentioned above in (i) and (ii). Table 6.3 lists all 24 key factors identified across the three general domains, specifying their quality and rationale. 
TABLE 6.3 Key factors in LSLA implementation processes

\begin{tabular}{|c|c|c|c|}
\hline & $\#$ & Key factor & Quality and rationale \\
\hline \multirow{9}{*}{ 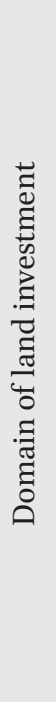 } & 1. & Origin of investors & Country of origin \\
\hline & 2. & Type of crop & Intention of investment \\
\hline & 3. & Time of investment & Year when land was allocated \\
\hline & 4. & Access to political power & Investors' access to political power including \\
\hline & & & $\begin{array}{l}\text { historical ties and political backing in host } \\
\text { country and country of origin }\end{array}$ \\
\hline & 5. & $\begin{array}{l}\text { Access to cheap labour } \\
\text { force }\end{array}$ & $\begin{array}{l}\text { Perceived and actual availability and price of } \\
\text { labour force }\end{array}$ \\
\hline & 6. & Size of company & $\begin{array}{l}\text { Overall power of company including access to } \\
\text { capital and stock exchange }\end{array}$ \\
\hline & 7. & CSR commitment & $\begin{array}{l}\text { Investors' commitments to corporate social } \\
\text { and environmental sustainability and a good } \\
\text { reputation }\end{array}$ \\
\hline & 8. & Size of concession & $\begin{array}{l}\text { Total size of land requested and granted for } \\
\text { investment }\end{array}$ \\
\hline \multirow{8}{*}{ 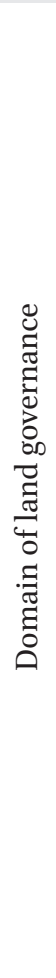 } & 9. & $\begin{array}{l}\text { Economic growth } \\
\text { strategies }\end{array}$ & $\begin{array}{l}\text { Government endeavours to push economic } \\
\text { growth through regional integration and } \\
\text { foreign direct investment (FDI) in land }\end{array}$ \\
\hline & 10. & Policies related to land & $\begin{array}{l}\text { Includes policies related to shifting cultivation, } \\
\text { land use planning, infrastructure development, } \\
\text { relocation, etc. }\end{array}$ \\
\hline & 11. & $\begin{array}{l}\text { Top-down granting of } \\
\text { concessions }\end{array}$ & $\begin{array}{l}\text { Central level officials granting concessions and } \\
\text { delegating implementation to lower } \\
\text { administrative levels }\end{array}$ \\
\hline & 12. & $\begin{array}{l}\text { Power of district/ } \\
\text { provincial officials }\end{array}$ & $\begin{array}{l}\text { Power of provincial and district officials } \\
\text { actively involved in granting rights and support } \\
\text { to investors }\end{array}$ \\
\hline & 13. & Experience with LSLAs & Decision makers' prior experience of LSLAS \\
\hline & 14 . & Patronage and corruption & $\begin{array}{l}\text { Patronage and corruption among different } \\
\text { stakeholders and also across sectors and levels }\end{array}$ \\
\hline & 15 . & Land tenure insecurity & $\begin{array}{l}\text { Legal pluralism and relative power differentials } \\
\text { of institutions governing land access and land } \\
\text { use rights }\end{array}$ \\
\hline & 16. & Land surveys & $\begin{array}{l}\text { Companies and/or government collecting } \\
\text { information on land, involved stakeholders, } \\
\text { and possible impacts }\end{array}$ \\
\hline
\end{tabular}




\begin{tabular}{|c|c|c|c|}
\hline & \# & Key factor & Quality and rationale \\
\hline \multirow{9}{*}{ 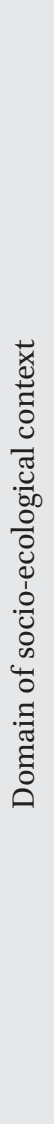 } & 17. & $\begin{array}{l}\text { Available and suitable } \\
\text { land }\end{array}$ & $\begin{array}{l}\text { Land availability as perceived by local people } \\
\text { or as constructed by powerful actors and } \\
\text { policies }\end{array}$ \\
\hline & 18. & Land cover and land use & $\begin{array}{l}\text { Pre-existing land use and land cover in areas } \\
\text { targeted for land investments }\end{array}$ \\
\hline & 19. & Logging & $\begin{array}{l}\text { Logging prior to investment is often seen as an } \\
\text { important incentive for investors or/and }\end{array}$ \\
\hline & & & authorities involved \\
\hline & 20. & $\begin{array}{l}\text { Biophysical factors and } \\
\text { topography }\end{array}$ & $\begin{array}{l}\text { Opportunities to acquire large and connected } \\
\text { plots of land; biophysical factors influencing } \\
\text { suitability such as soil, climate, altitude }\end{array}$ \\
\hline & 21. & Historical ties & $\begin{array}{l}\text { Confidence of rural population and local } \\
\text { authorities in investors from neighbouring } \\
\text { regions and countries based on a shared } \\
\text { history }\end{array}$ \\
\hline & 22. & $\begin{array}{l}\text { Capability and assets of } \\
\text { villagers }\end{array}$ & $\begin{array}{l}\text { Includes factors of well-being/poverty and } \\
\text { ethnicity, as well as social relations, networks, } \\
\text { etc. of villagers and their representatives }\end{array}$ \\
\hline & 23. & Accessibility & $\begin{array}{l}\text { Accessibility in travel time to nearby city } \\
\text { centres, processing factories, and border } \\
\text { crossings. Defined by topography, } \\
\text { infrastructure, and land use }\end{array}$ \\
\hline & 24. & Land allocation & $\begin{array}{l}\text { Final identification and allocation of land to } \\
\text { the investor as a new land user }\end{array}$ \\
\hline
\end{tabular}

SOURCE: AUTHORS.

3.2.2 Meta-Analysis of Case Studies and Role of Key Factors Having defined domains and representative sets of key factors, we were then able to focus in a comparative manner on our main object of interest: the diverse interactions between these key factors. For each case study, we assessed any possible interactions between the 24 key factors in either direction (i.e. influencing or being influenced). Referring back to the original research results of every case study, we assessed any possible interaction between any two factors. Based on their knowledge of the case-study settings, the researchers involved rated each possible interaction between key factors on a scale from absent (0), through weak (0.5) and moderate (1.0), to strong (2.0). This rating 
system enabled us to calculate the average strength of an interaction between any two key factors across all 15 case studies.

The matrix in Figure 6.3 summarises the most important interactions observed in each of the 15 case studies (shaded in dark gray). For example, reading across row 1 we see that the key factor $(\mathrm{KF})$ Origin of Investor (KF 1) has a direct and strong influence on Access to Political Power (KF 4) and on the Size of Concession (KF 8). Similarly, reading down column 17 we see that Available Land ( $\mathrm{KF} 17$ ) is influenced by various key factors from different domains, including: Type of Crop (KF 2), Time of Investment (KF 3), and Size of Concession (KF 8) from the land investment domain; Policies Related to Land (KF 10), Land Tenure Insecurity (KF 15), and Land Surveys (KF 16) from the governance domain; and Capability and Assets of Villagers (KF 22), Accessibility (KF 23), etc. from the domain of socio-ecological context. Among other things, this powerfully demonstrates that, in practice, 'available land' (KF 17) cannot be observed strictly by means of remote sensing or according to environmental indicators; rather, it is something that is constructed based on power relations between actors and according to relevant policies.

Beyond looking at influences from a first factor on a second factor, we can use the matrix to examine how a second factor influences a third factor, and so on. This makes it possible to describe whole chains of interactions. For example, the Time of Investment ( $\mathrm{KF}_{3}$ ) is seen to strongly influence the Power of District/Provincial Officials (KF 12); indeed, during the early years of concession granting, alliances between provincial officials and investors flourished, and land deals did not require national-level approval. Provincial officials (KF 12), in turn, strongly influence the way Land Surveys are conducted (KF 16). As a consequence, provincial officials are able to define Available Land (KF 17) according to their own interests and those of investors. Finally, this definition of Available Land ( $\mathrm{KF} 17$ ) determines Land Allocation (KF 24) and the granting of contiguous plots and large Sizes of Concessions (KF 8).

Perhaps of even greater interest from a policy perspective is to identify which key factors play the biggest role in particular outcomes of the LSLA implementation process. Our meta-analysis provides information on the general role played by each factor, in particular how strongly each factor interacts with others in the system and whether it exerts or is subject to more influence overall. To this end, we calculated: (i) the sum of the influences that each factor exerts (referred to as the active sum, or As, for each row), and (ii) the sum of the influences that each factor is subject to (referred to as the passive sum, or Ps, for each column). By comparing the active sum of any given factor with its passive sum, we can calculate its activity ratio $(\mathrm{AR}=\mathrm{AS} / \mathrm{PS})$ - that is, whether and to what extent it exerts a greater influence than it is subject to. In addition, it is 

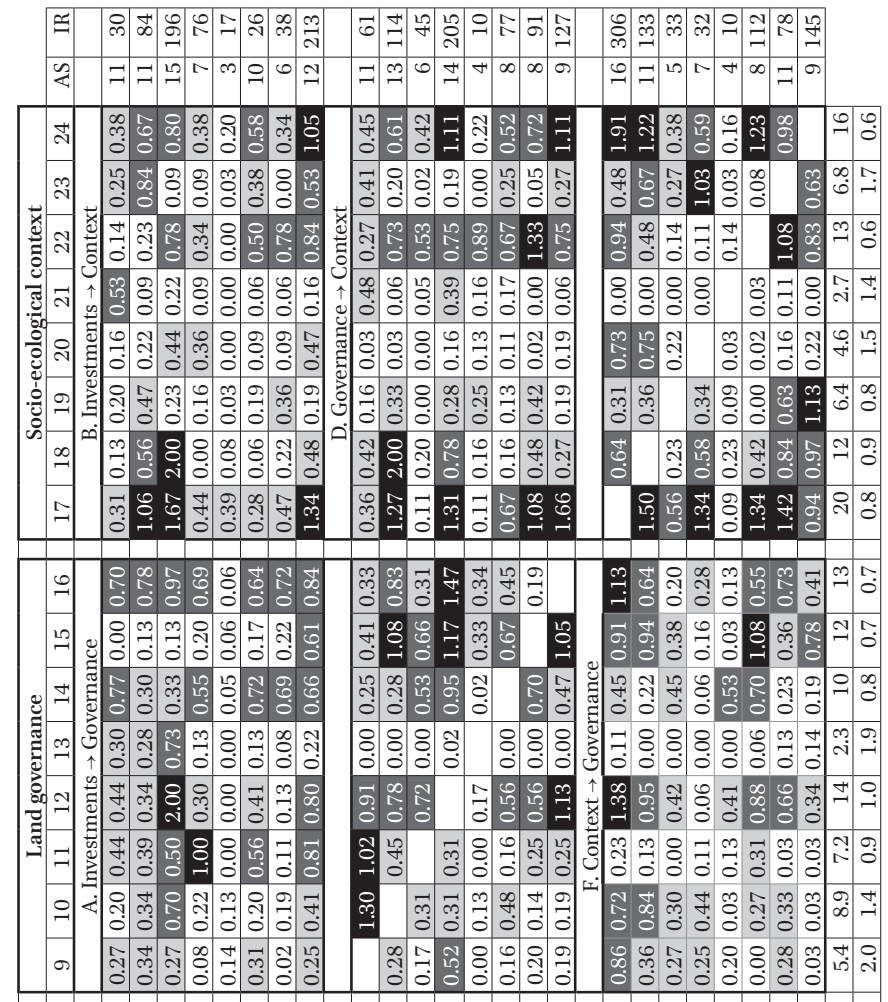

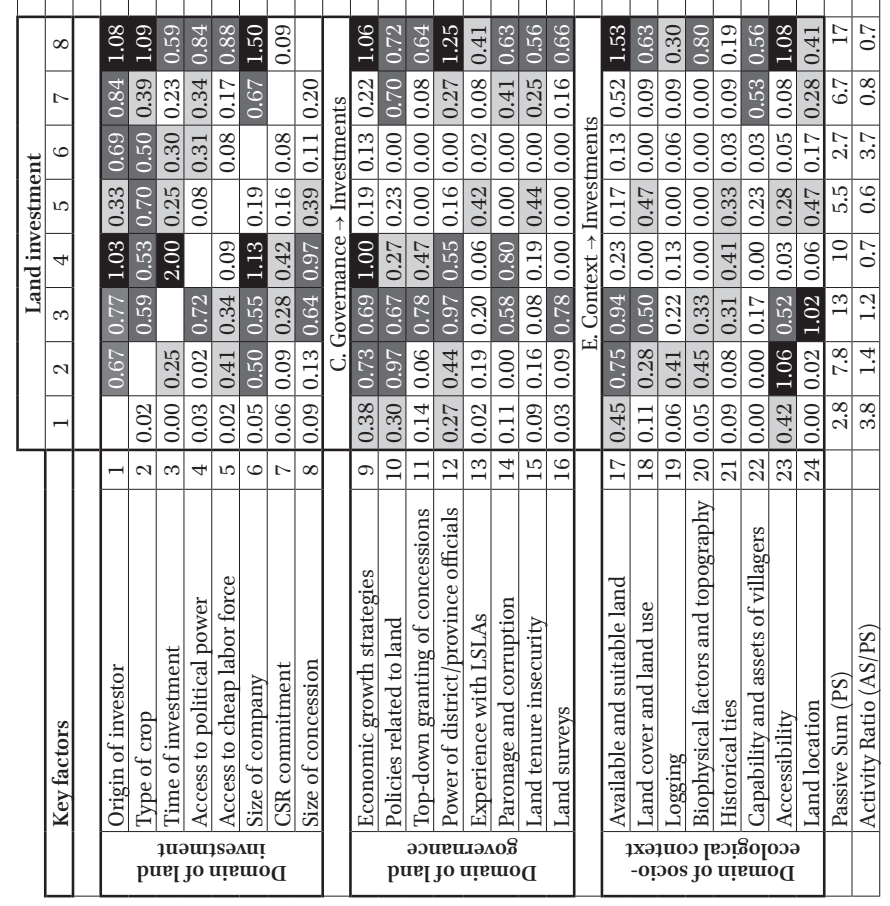

o

iิ $)$

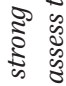

โ

$\frac{2}{2} \frac{1}{0}$

\$ัฐ

₹.

30

:

$\approx$

ह

:

क

ङे

잉

ฐ

$\Xi \Xi$

เิ

:

ऐ্

ม क

ปี ธี

के क

है

放

ఖँ . స

ปิ

व.

¿

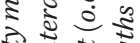

: $\cong$ ป

.

उँ

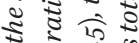

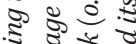

के

के है क

कृ ₹

की है 1

ठु के

ว.

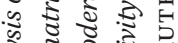

స్తิ ई ई

ปิ

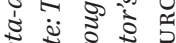

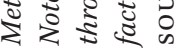

0
0
0
01
0
0
0 
very useful to calculate how strongly each factor interacts with other factors. This can be done by multiplying the active sum by the passive sum to arrive at the total strength of interaction ( $\left.\mathrm{IR}=\mathrm{AS}{ }^{*} \mathrm{PS}\right)$.

Next, we identified all the factors that display activity ratios where the active sum outweighs the passive sum (AS/PS >1). These factors may be seen as having the biggest influence on the outcomes of the implementation process. In the land investment domain, these factors comprise Origin of Investor (KF 1), Type of Crop (KF 2), Time of Investment (KF 3), and Size of Company (KF 6). Indeed, the case studies we analysed showed that large companiesmainly from Vietnam and China-that arrived early and invested in forestry concessions (e.g. rubber, eucalyptus) were generally able to obtain large plots of land, where they wanted them, with little to no resistance or administrative obstacles. By contrast, relatively small companies and latecomers experienced significantly more problems and were required to cooperate with district officials, to conduct land surveys, and to negotiate the allocation of smaller plots of land with villagers. In the land governance domain, the most influential key factors comprise national-level Economic Growth Strategies (KF 9) and Policies Related to Land ( $\mathrm{KF}$ 10), as well as different actors' Experience with LSLAS (KF 13). In the socio-ecological context domain, only Accessibility (KF 23) of urban centres appears to play an influential role; Biophysical Factors (KF 20) and Historical Ties (KF 21) exhibit positive activity ratios but appear only weakly interrelated.

Finally, we identified all the factors that display activity ratios where the passive sum outweighs the active sum (AS/PS $<1$ ) but which are highly interrelated. These factors may not have the power to influence the outcomes of the implementation process; however, because they are strongly influenced by many other factors, they serve as useful indicators of the type of implementation process in question. The most important of these indicative factors are the quantity and quality of Available Land ( $\mathrm{KF} 17$ ) and Land Allocation (KF 24), which vary substantially depending on whether the corresponding implementation process occurs in a more authoritarian/top-down or participatory/bottom-up manner. Further, Size of Concession (KF 8) serves as an excellent indicator of the type of implementation process, since careful negotiations and planning processes usually result in more fragmented, modestly sized plots than originally anticipated or desired by investors. Lastly, the following factors serve as useful indicators of the monitoring of the implementation process - that is to say, in terms of the role they play: the type and quality of Land Surveys conducted ( $\mathrm{KF} 16$ ), the role attributed to pre-existing Land 
Use (KF 18), and the Capability and Assets of Villagers (KF 22). The fact that villagers' capabilities only serve as an indicator and not as an influential factor suggests that villagers' empowerment is subject to very real constraints. Indeed, from a systemic perspective, other factors have a much bigger role in the outcome of LSLA implementation processes.

3.3 Archetypes of LSLA Implementation Processes and Resulting Typology As shown above, our meta-analysis enabled generalisation, based on 15 case studies, of the importance of different key factors in the LSLA implementation process. As we have also seen, however, the interactions between these factors display different qualities and levels of strength, involve feedback mechanisms and chain-like effects, and ultimately lead to different outcomes. In an effort to account for such differentiations in our meta-analysis, we looked for recurrent linkages between the key factors, links that may point to archetypal patterns. So defined, the resulting archetypes could provide the basis for a working typology of LSLA implementation processes.

For this purpose, we analysed how the three main domains of the implementation processes - namely, land investment, land governance, and socio-ecological context-influenced each other. For example, do the combined factors from the land governance domain exert a greater influence on the combined factors from the land investment domain or vice versa? To find out, we analysed the matrix of influences for every case study (Figure 6.3) and calculated the balance of influences between any two domains of the implementation process. Our analysis of all 15 case studies revealed four distinct archetypes in terms of the way the main domains influence each other (Figure 6.4). They are detailed below.

\subsubsection{Archetype 1: Marginal People}

Our analysis of the interrelations between the selected key factors revealed the following pattern among eight of the 15 case studies: a net influence exerted by the domains of land governance and land investment, respectively, on the domain of the socio-ecological context; and, at the same time, a net influence exerted by land investment on the land governance domain (observe the directions of the arrows in the outer ring of Figure 6.5). Based on this shared pattern, we posit an implementation-process archetype we refer to as 'Marginal People': land acquisitions in this category are essentially steered by the claims of powerful external actors, irrespective of local realities, thus exploiting and exacerbating the weak position of marginalised populations. 


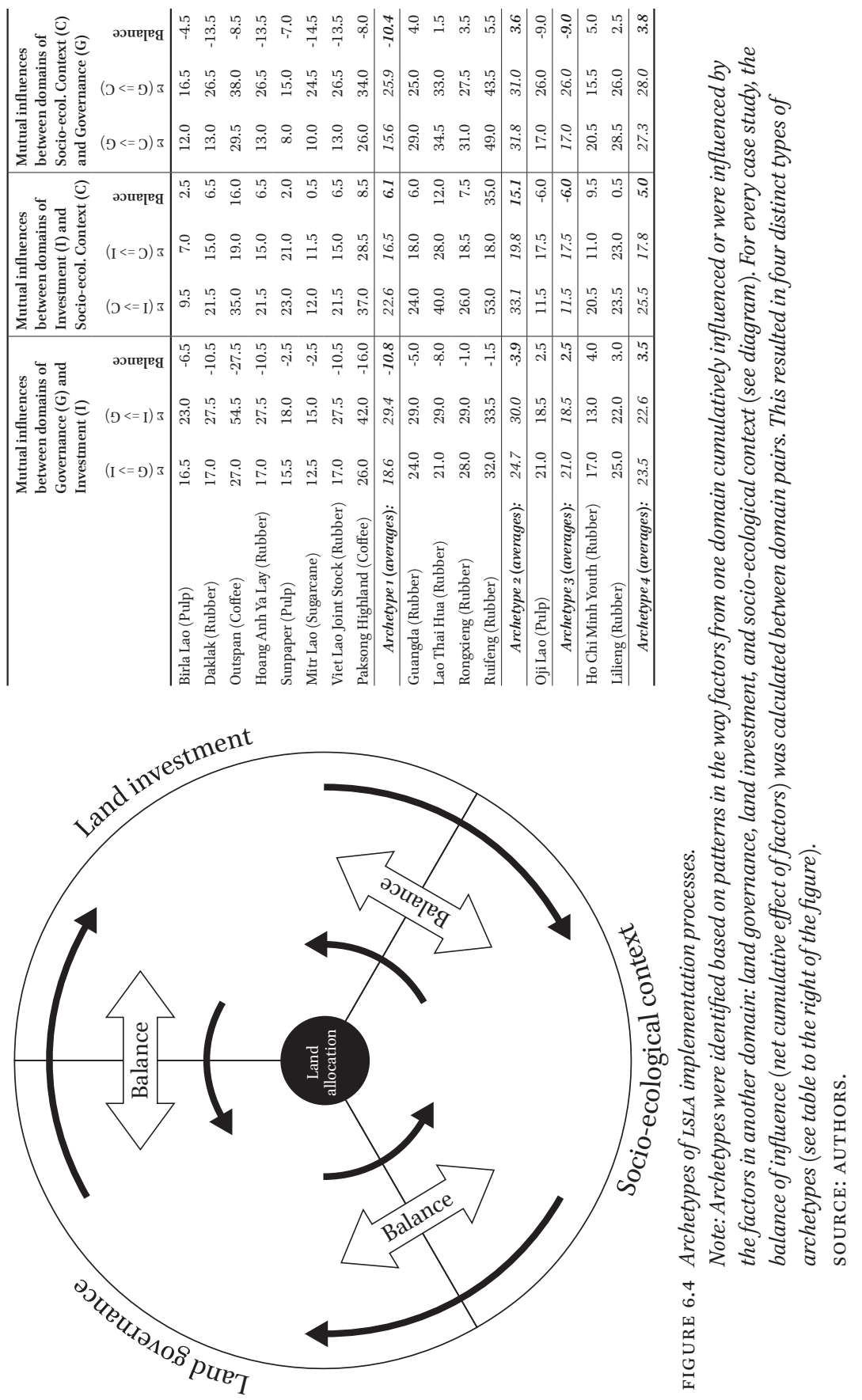




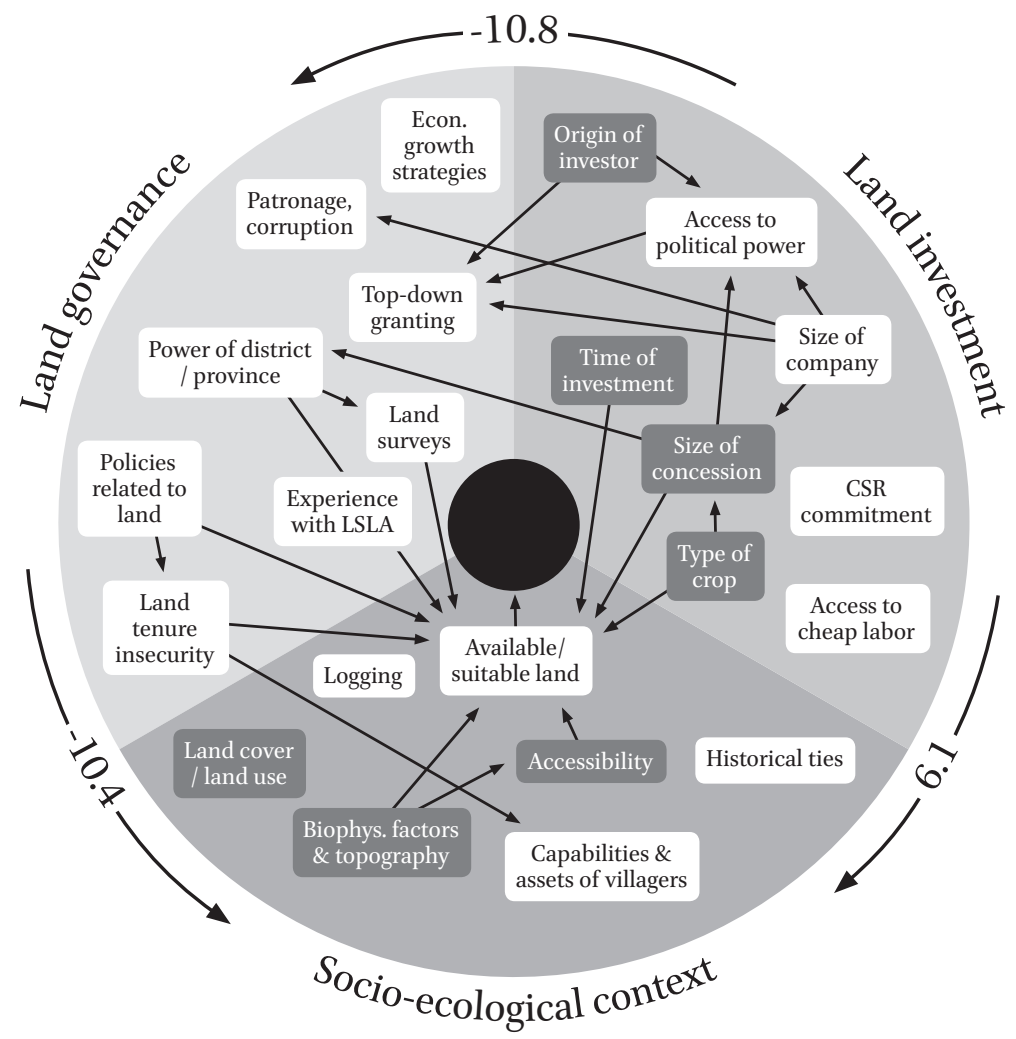

FIGURE 6.5 Archetype 'Marginal People'.

Note: Recurrent interactions among key factors in LSLA implementation processes (displaying an average rating $\geq 1.25$ ). The outer arrows indicate the net balance of mutual influence between domains. SOURCE: AUTHORS.

For the majority of the case studies in this category, analysis of the recurrent interactions between key factors (Figure 6.5) reveals strong ties in the land investment domain. Origin of Investor ( $\mathrm{KF}$ 1) - typically neighbouring countries such as Vietnam, China, or Thailand-is positively correlated with the Size of Company (KF 6) and has a favourable influence on investors' Access to Political Power (KF 4). In many cases, strong alliances were established between investors and provincial authorities on either side of nearby national borders. These factors, corresponding to strong political and economic backing, in turn influence the intended Size of Concession (KF 8) — relatively large in these case studies $(44,500$ ha for pulp concessions and 10,000 ha for rubber concessions, on average). The strengths of the land investment domain led to 
recurrent influences on both the domain of socio-ecological context and on the domain of land governance. Notably, the definition of Available and Suitable Land (KF 17) appears to be defined by the Type of Crop (KF 2) and on the Size of Concession (KF 8) requested. Further, the efficient Top-Down Granting of Concessions (KF 11) corresponds to investors who arrived early on. Due to their lack of Experience with LSLAS (KF 13), local authorities and villagers could be easily swayed by empty promises. While key factors of the local socio-ecological context may influence the definition of Available and Suitable Land (KF 17) to a certain degree, they have limited influence on the Time of Investment (KF 3), Type of Crop (KF 2), or Size of Concession (KF 8). At the same time, key factors from the land investment domain influence processes in the domain of land governance. Investors' Access to Political Power (KF 4) and economic power corresponds to Top-Down Granting of Land Concessions (KF 11), which limits the Power of District/Provincial Officials (KF 12). Such access to power also strongly influences the conduct of Land Surveys ( $\mathrm{kF} 16$ ), contributing to greater Land Tenure Insecurity ( $\mathrm{KF}$ 15). These factors together influence what is defined as Available and Suitable Land (KF 17) and to what degree the Capability and Assets of Villagers come into play (KF 22).

\subsubsection{Archetype 2: Marginal Governance}

Four cases of rubber investments from Chinese and Thai companies revealed a different pattern of recurrent interactions among key factors. While the net influence emerging from the land investment domain still dominates the influence of the socio-ecological context and the land governance domains, respectively, key factors in the socio-ecological context now clearly affect land governance. We refer to this archetype as 'Marginal Governance', since land governance here is shaped by specificities of the socio-ecological context, but still remains largely under the control of the land investment domain.

The recurrent interrelations of key factors in these four case studies (Figure 6.6) once again point to strong investors, namely two relatively small and two large companies (Ruifeng from China, and Lao Thai Hua from Thailand), which were initially granted concession areas of 10,000 ha and 30,000 ha, respectively. These large investments exerted powerful influences on the Power of Provincial/District Officials (KF 12) and the implementation of Land Surveys (KF 16). In addition, the Size of Concession (KF 8), Time of Investment (KF 3), and Type of Crop (KF 2) dictated what land was deemed available and needed to be allocated.

Also notable in these cases, key factors of the socio-ecological context were not simply overruled by outside forces. We observe in Figure 6.6 that Available 


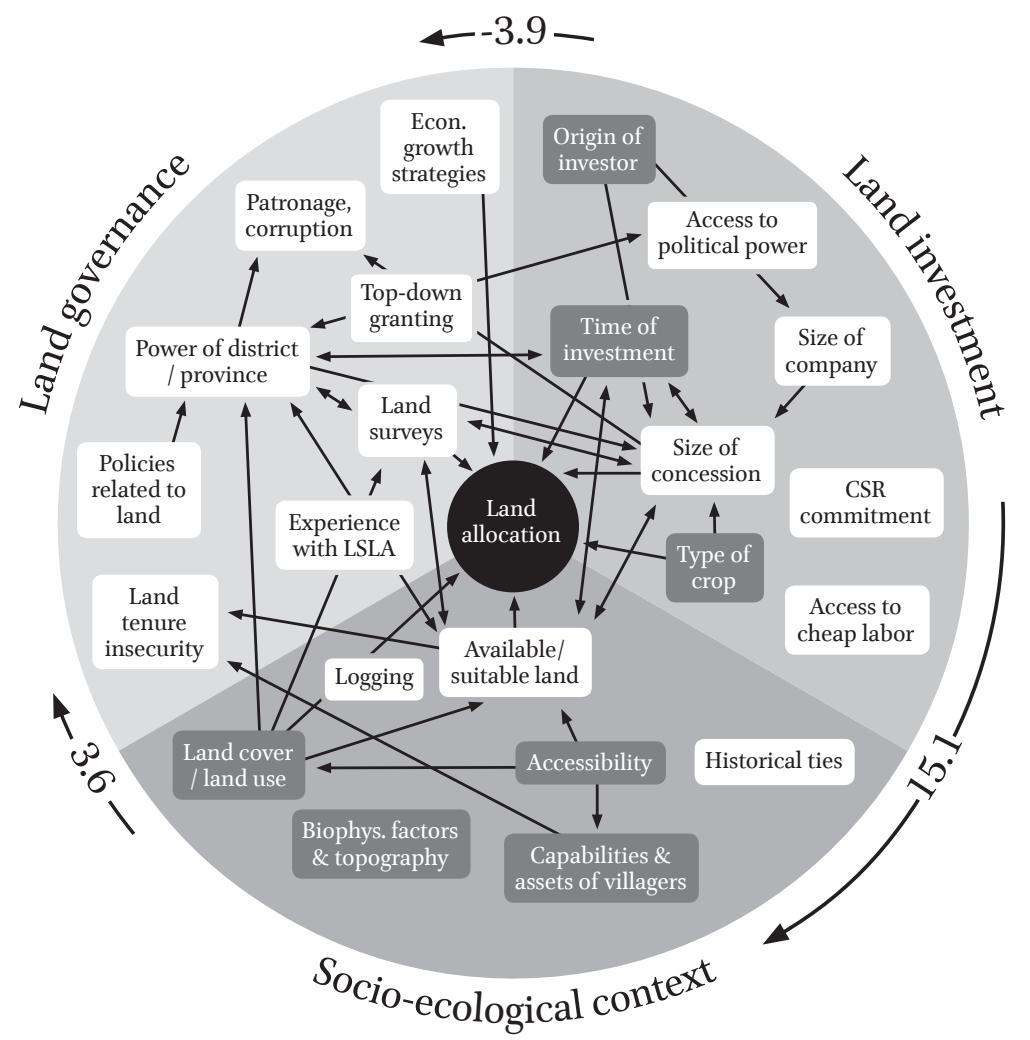

FIGURE 6.6 Archetype 'Marginal Governance'.

Note: Recurrent interactions among key factors in LSLA implementation processes (displaying an average rating $\geq 1.25$ ). The outer arrows indicate the net balance of mutual influence between domains. SOURCE: AUTHORS.

Land and Suitable Land (KF 17), Land Cover and Land Use (KF 18), Capability and Assets of Villagers ( $\mathrm{KF} 22$ ), and Accessibility ( $\mathrm{KF} 23$ ) exerted an influence on the Size of Concession (KF 8) and the Power of District/Provincial Officials (KF 12), and shaped the outcomes of the Land Survey (KF 16). In other words, the definition of available land and the final allocation of land were also influenced by people, by pre-existing land use, topography, and accessibility. This new pattern can be explained as follows: firstly, large companies with higher CSR standards (and a sensitivity to reputational risks), such as the Lao Thai Hua company, explicitly followed a bottom-up approach, paying careful attention to the context of the investment. Others, such as the Rongxieng Company, 
also adopted a more bottom-up approach, but only following initial bad experiences using an authoritarian approach (involving use of armed soldiers). The key characteristics of this archetype of implementation processes are strong investors who maintain control but pay careful attention to the socioecological context and allow it to shape land governance. Such investors are willing to accept a slower LSLA implementation process, smaller concessions than originally planned, or the subdivision of concessions into multiple plots. In one case, such perceived downsides were compensated for by means of high-value timber-extraction activities during land clearing.

\subsubsection{Archetype 3: Marginal Investments}

One case study involving a Japanese pulp production company exhibited a unique pattern of LSLA implementation, which did not fit with the other archetypes. In this case, the land investment domain was clearly dominated by factors in the land governance and socio-ecological context domains, ultimately threatening the whole project. While it is only a single case, we wish to highlight it as it may point to a unique archetype that we will refer to as 'Marginal Investments'.

In this type of LSLA implementation process (Figure 6.7) the company experienced a very smooth start because it was able to take over a pre-existing concession and benefited from Access to Political Power (KF 4) through highlevel diplomatic ties. Despite its promising start, however, years have passed and the company continues to struggle to actually have the land allocated. They lack support from District/Provincial Officials (KF 12) and there is no longer enough Available and Suitable Land (KF 17) due to the earlier 'land rush' (Time of Investment-KF 3). Villagers and authorities from districts/provinces have also learned from past Experience with LSLAS (KF 13) and are now able to negotiate better conditions for land deals. In such cases, the Capability and Assets of Villagers (KF 22) and local authorities-that is, their ability to resist coercion or financial temptations and to negotiate effectively with companies and district officials-considerably influence contractual modalities (e.g. contract farming or concession type) and the overall terms of investment (e.g. land area, compensation). This has led the company in question to pursue a more bottom-up approach, fulfilling CSR commitments. However, this approach has allowed local socio-ecological factors-pre-existing Land Cover and Land Use (KF 18) and lack of Available Land and Suitable Land (KF 17) to act as constraints, increasing the risk of investment failure. In response, the company recently diversified the crops it intends to produce from eucalyptus to a variety of agricultural products, and is conducting market and suitability studies. 


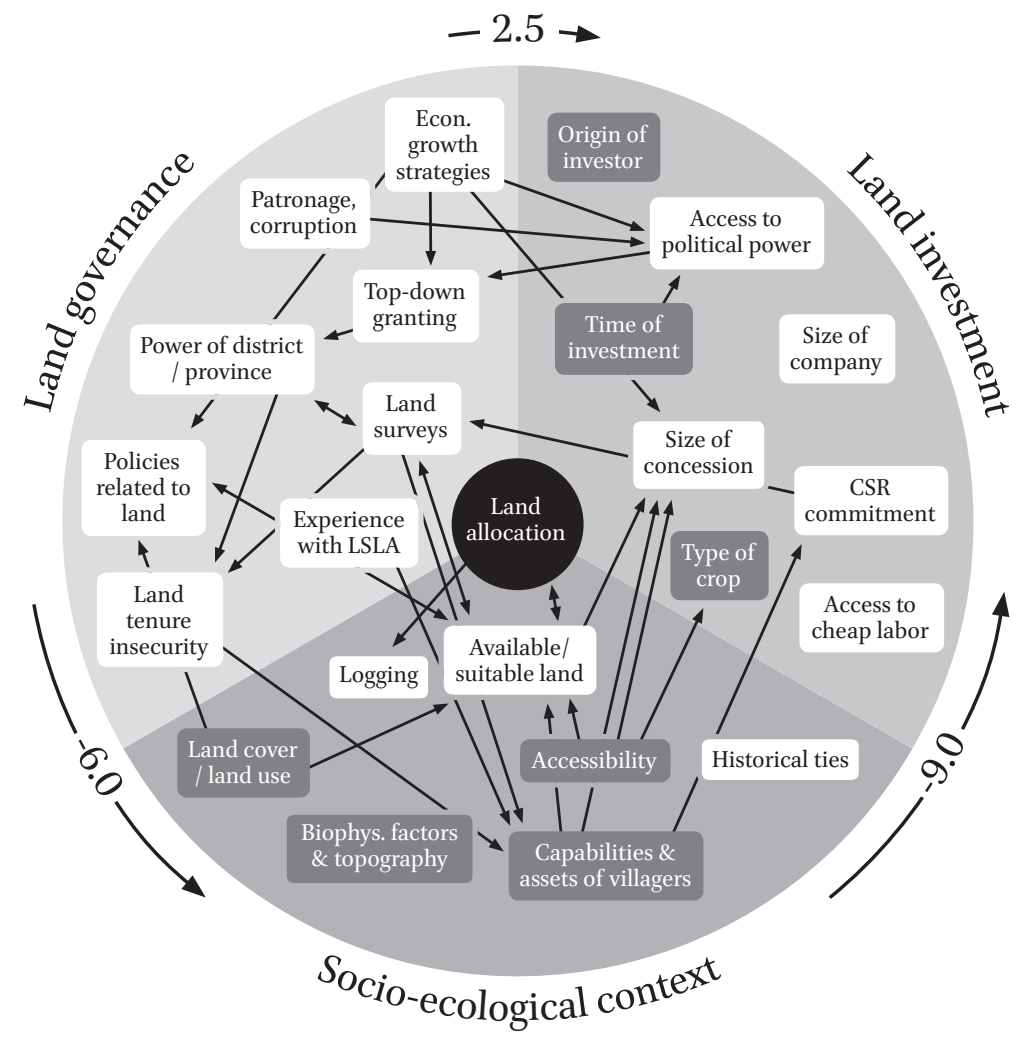

FIGURE 6.7 Archetype 'Marginal Investment'.

Note: Recurrent interactions among key factors in LSLA implementation processes (displaying an average rating 21.25 ). The outer arrows indicate the net balance of mutual influence between domains. SOURCE: AUTHORS.

\subsubsection{Archetype 4: Marginal Land}

Finally, two case studies-involving a Vietnamese and a Chinese rubber investment, respectively - revealed yet another pattern of LSLA implementation. We believe these companies provide a good example of effectively targeting agricultural investments towards underused land, and we refer to the corresponding archetype as 'Marginal land'. In these cases: the socio-ecological context mainly influences land governance; land governance controls the land investment domain; and land investment, in turn, shapes the socio-ecological context (Figure 6.8).

First of all, the recurrent interactions observed between key factors indicate limited economic and political power on the part of the companies 


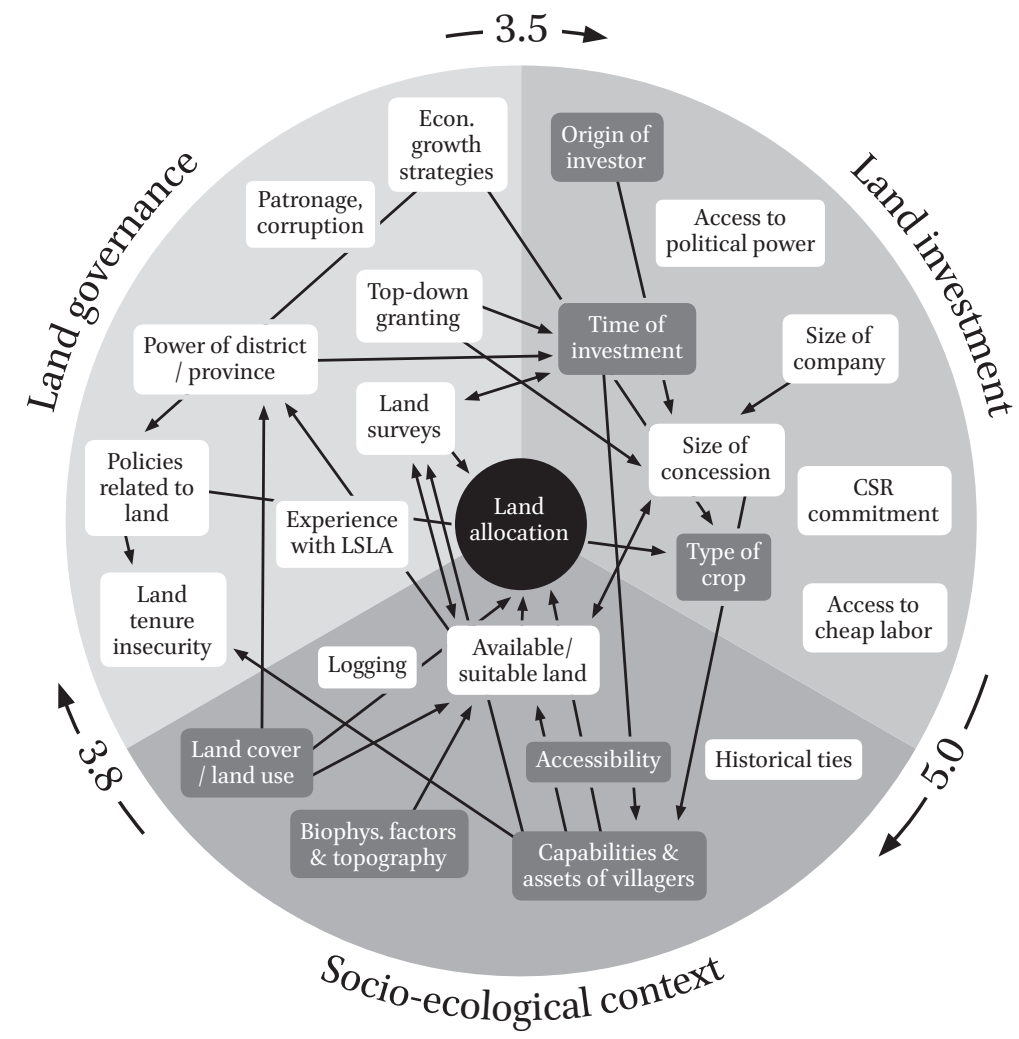

FIGURE 6.8 Archetype 'Marginal Land'.

Note: Recurrent interactions among key factors in implementation

processes of large-scale land acquisition (manifesting an average rating 21.25 ). Outer arrows refer to the net balance of mutual influences between domains.

SOURCE: AUTHORS.

involved. While the land investment domain had some influence on the way Land Surveys (KF 16) were carried out, it did not significantly influence Policies Related to Land (KF 10) or Top-Down Granting of Concessions (KF 11). This prevented the investors from manipulating aspects of land governance to their advantage. The search for Available and Suitable Land (KF 17) proved to be a very difficult endeavour for the investors. As they arrived later than other companies in the respective regions, their own interests - for example, obtaining a large Size of Concession (KF 8) or producing a specific Type of Crop (KF 2)played a limited role in defining what was deemed available. They were obliged to negotiate locally regarding available land and, as a result, key factors of the 
socio-ecological context — such as Land Cover and Land Use (KF 18), Biophysical Factors and Topography ( $\mathrm{KF} 20$ ), Accessibility ( $\mathrm{KF} 23$ ), and Capability and Assets of Villagers ( $\mathrm{KF} 22$ ) - played a significant role. Though it was a lengthy and frequently complicated process, the resulting Land Allocation ( $\mathrm{KF} 24$ ) was the most inclusive of all those observed, with both villagers and investors agreeing to it. These actors then sought support in terms of land governance from provincial and district authorities, eventually requesting Land Surveys (KF 16) and formal recognition of the agreements. Ultimately, these processes positively influenced the implementation of Policies Related to Land ( $\mathrm{KF} 10$ ) and Land Tenure Insecurity (KF 15) (the latter in the sense that such insecurity was reduced).

\section{Synthesis and Discussion}

In previous sections, we have presented the results of applying two complementary approaches to the analysis of LSLAs, in an effort to provide better evidence for policymaking. On the one hand, we conducted a spatially referenced analysis of land acquisitions in Laos and Cambodia, revealing patterns of investor type, investment purpose (sub-sector), and socio-ecological contexts. On the other, we conducted a process-based analysis of LSLA implementation, reaching from initial negotiations to the final allocation of land. This was done by means of a meta-analysis of case studies in which we identified recurrent interactions between selected key factors of LSLA implementation. This enabled us to identify possible archetypes that could serve as a basis for a working typology of LSLA implementation processes.

Both approaches are capable of generating policy-relevant information, but each has clear limitations on its own (discussed below). That fact brings us back to our guiding question: can distinct spatial patterns be tied to specific types of LSLA implementation processes by means of common indicators? This would enable observers to either interpret spatial patterns in terms of underlying implementation processes, or to validate and generalise case-study findings regarding implementation processes to inform policies at higher spatial levels.

Our spatial analysis of LSLA inventories revealed two general patterns. (1) Numerous regional investors and some domestic investors have engaged in forestry sub-sectors, mainly focussing on rubber and eucalyptus or acacia plantations. The corresponding concessions are generally large, contiguous plots of land found in somewhat inaccessible landscapes once classified 
as forest or shrub land. The populations affected by these concessions are generally poorer than the respective national poverty line of each country and often practice small-scale agriculture (mainly, in Laos, shifting cultivation). (2) A mix of regional, domestic, and some international investors have engaged in agricultural sub-sectors. Their concessions are generally smaller and often compete with pre-existing cropping mosaics cultivated by smallholders. The affected areas are usually relatively accessible and populated by less-poor people in Laos and by poorer people in Cambodia.

These insights are consistent with a growing body of evidence showing that LSLAS are a strong driver of agrarian transition in South-East Asia (Anseeuw et al., 2012). LSLAs have increased exponentially, making rural areas the site of fierce competition over resources in settings where powerful investors from riparian countries play a key role (Schönweger et al., 2012). Our analysis shows that optimistic assumptions about investment mainly flowing to 'marginal land' - that is, land that is unused yet suitable for agriculture - are fundamentally flawed (Borras Jr. et al., 2011; Cotula et al., 2009; Messerli et al., 2014). Instead, land concessions are increasing resource competition, affecting two vulnerable groups in particular: smallholders in densely populated cropping mosaics; and poorer ethnic minorities in forest mosaics where shifting cultivation is common. Overall, spatial, quantitative analysis of land concessions clearly demonstrates that LSLAs are and will remain a driving force of agrarian transition in the region. Given the advanced stage of expansion into agricultural and forested landscapes and existing conflicts with affected land users, policymaking questions should no longer be limited to whether to permit, prevent, or regulate the arrival of LSLAs in the area. Rather, the focus must increasingly shift to policies relevant to conflict resolution, labour issues, and outmigration as new drivers of poverty.

In view of such questions, our analysis of spatial patterns remains very coarse and provides insufficient differentiation. While some general correlations can be posited between the origins of investors, the type of operations they conduct, and the socio-ecological contexts targeted, we neither understand the causalities of LSLA implementation processes nor can we identify the precise spatio-temporal contexts with the most vulnerable environments and populations.

However, our meta-analysis of case studies reveals a more differentiated picture of the processes behind the implementation of LSLAs. The majority of our case studies pointed to an archetype of LSLA implementation processes that we have termed 'Marginal People'. In this sort of authoritarian, top-down LSLA implementation process, 'available land' is defined less according to local socio-ecological factors than it is according to factors from the domains of 
investment and land governance. Contrary to the analysis of spatial patterns, we found that this type of implementation process can be observed both in the forestry sector and in the agricultural sector, encompassing crops as varied as rubber, eucalyptus, coffee, and sugar cane. Also, it involved investors from different countries of origin, both regional and international. Closely related to this type of LSLA implementation is the archetype we refer to as 'Marginal Governance'. It too is characterised by a strong investment domain but is somewhat shaped by the socio-ecological context, providing an empowerment to the socio-ecological context vis-à-vis policy pressures. Nevertheless, the economic and political power wielded by investors means that land governance is ultimately constrained in its effectiveness.

The remaining case studies were attributed to two more recent types of LSLA implementation processes. One type we refer to as 'Marginal Investments', in which investors struggle to obtain land. Accepting that available land-as defined by local land users-is very scarce, and lacking government support, investors in this category face the very real prospect of total failure. Investors also face possible failure in the final archetype we identified, 'Marginal Land'. This category comprises rubber companies that arrived late to the region and were forced to follow a more bottom-up approach in their search to find suitable land - by now exceedingly scarce. Their negotiations with local land users resulted in the most inclusive form of LSLA implementation we observed. After reaching an agreement about available land, villagers and investors jointly sought the support of district and provincial land governance institutions, which in turn lent their support to the investment domain.

Our analysis of LSLA implementation processes reveals various policyrelevant insights. First, we found that authoritarian forms of implementation dominate, as was suggested by the spatial patterns identified earlier. However, in contrast to our initial spatial observations, we found that investors from other countries besides Vietnam and China were also involved in top-down modes of implementation. In general, authoritarian implementation processes appear to be associated with powerful companies who arrived on the scene early, just after foreign direct investment had received policy approval, and had access to political elites within the government. These sorts of implementation processes occur very quickly, leaving little space for policy intervention. In these cases, openings for local people to voice their interests only appear to occur when they are granted by the investors themselves, whether for strategic reasons or because of commitments to corporate social responsibility.

Second, we found that new, more inclusive models of implementation emerge as land concessions begin to proliferate. Notably, these emerging models of implementation may provide spaces for policy intervention, whether at 
the national, provincial, or local level. Yet, it should be noted that they have not emerged due to regulatory measures, but rather due to the increasing scarcity of available land, competition between investors, and the learning processes of actors at different policy levels. One archetype emerging in this advanced stage of land acquisitions is that of failing land investments. This trend also appears to be reflected globally, as evidenced by the high rates of abandoned deals found in the Land Matrix (Land Matrix Partnership, 2014). Notably, failed deals could also provide space for a policy reboot in favour of more inclusive forms of land investment and agricultural development. Finally, the last archetype we identified-'Marginal Land' - points to alternative modes of agricultural investment that are actually beginning to occur. They appear to materialise once socio-ecological constraints - for example, demographic and environmental realities-begin to outweigh economic and political power. This newly emerging archetype has not received a lot of attention so far, but may come to play an increasingly important role worldwide.

We believe that such archetypes of implementation processes could contribute to a better, more differentiated and policy relevant understanding of LSLAS as driving forces of agrarian transitions. But this requires us to validate and generalise such archetypes to inform policies at higher spatial levels. Ideally, this could be done by linking our process-based archetypes with observable place-based (spatially referenced) patterns of LSLAs. In other words, we wish to identify whether these archetypes display spatial signatures that can be extrapolated using spatio-temporal data sets spanning larger geographic areas. Table 6.4 lists the key factors of our process-based archetypes and highlights the key factors for which spatio-temporal data sets are readily available.

As seen in Table 6.4, the key factors for which data from inventories and spatial layers are available (shaded rows in Table 6.4) only marginally overlap with the most important indicators of the different archetypes of LSLA implementation processes. With the exception of the Size of Concessions, it seems that no other key factor differentiating the four archetypes can be quantified with currently available spatio-temporal data sets. Conversely, many of the indicators that are decisive to LSLA implementation processes are difficult or impossible to capture fully using spatially explicit, country-level data; the most prominent example being Available and Suitable Land (KF 17). No statistics or map can adequately capture the characteristics of this factor. Correspondingly, spatial signatures differentiating these four archetypes can scarcely be extrapolated in time and space. However, a closer look at the indicators shows that expanding the information collected by existing inventories could make a big difference. If factors such as Time of Investment (KF 3) and characteristics of 
TABLE 6.4 Synthesising implementation processes and spatial patterns of land acquisitions

\begin{tabular}{|c|c|c|c|c|c|c|}
\hline & Key factors & & $\begin{array}{l}\text { Marginal } \\
\text { people }\end{array}$ & $\begin{array}{l}\text { Marginal } \\
\text { governance }\end{array}$ & $\begin{array}{l}\text { Marginal } \\
\text { investment }\end{array}$ & Marginal land \\
\hline \multirow{8}{*}{ 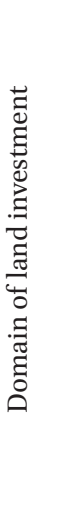 } & Origin of investor & 1 & & & & \\
\hline & Type of crop & 2 & & & & \\
\hline & Time of investment & 3 & Early arrivals & Early arrivals & & Late arrivals \\
\hline & Access to political power & 4 & $\begin{array}{l}\text { High level ties, } \\
\text { diplomatic }\end{array}$ & & & \\
\hline & Access to cheap labor force & 5 & & & & \\
\hline & Size of company & 6 & Large size & Large size & $\begin{array}{l}\text { Large as well } \\
\text { as small }\end{array}$ & $\begin{array}{l}\text { Large as well as } \\
\text { small }\end{array}$ \\
\hline & CSR commitment & 7 & & Generally high & & \\
\hline & Size of concession & 8 & $\begin{array}{l}\text { Large, connected } \\
\text { plots }\end{array}$ & $\begin{array}{l}\text { Large, } \\
\text { connected plots }\end{array}$ & & Small, flexible \\
\hline \multirow{7}{*}{ 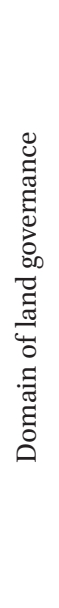 } & $\begin{array}{l}\text { Economic growth } \\
\text { strategies }\end{array}$ & 9 & & & & \\
\hline & $\begin{array}{l}\text { Policies related to land } \\
\text { Top-down granting of } \\
\text { concessions }\end{array}$ & $\begin{array}{l}10 \\
11\end{array}$ & & & & \\
\hline & $\begin{array}{l}\text { Power of district/province } \\
\text { officials }\end{array}$ & 12 & $\begin{array}{l}\text { High, } \\
\text { influencing land } \\
\text { surveys }\end{array}$ & $\begin{array}{l}\text { Weak, } \\
\text { infuenced by } \\
\text { investment }\end{array}$ & High & $\begin{array}{l}\text { Strong, drawing } \\
\text { on soc.-ecol. } \\
\text { context }\end{array}$ \\
\hline & Experience with LSLAS & 13 & & & & \\
\hline & Patronage and corruption & 14 & & & & \\
\hline & Land tenure insecurity & 15 & & & & \\
\hline & Land surveys & 16 & $\begin{array}{l}\text { Not or partly } \\
\text { implemented }\end{array}$ & Implemented & $\begin{array}{l}\text { Carefully } \\
\text { implemented }\end{array}$ & $\begin{array}{l}\text { Carefully } \\
\text { implemented }\end{array}$ \\
\hline \multirow{5}{*}{ 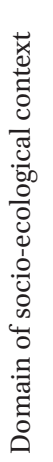 } & Available and suitable land & 17 & $\begin{array}{l}\text { Defined by } \\
\text { investment and } \\
\text { governance }\end{array}$ & $\begin{array}{l}\text { Defined by } \\
\text { investment and } \\
\text { soc.-ecol. } \\
\text { context }\end{array}$ & $\begin{array}{l}\text { Defined by } \\
\text { soc.-ecol. } \\
\text { context }\end{array}$ & $\begin{array}{l}\text { Defined by } \\
\text { investment and } \\
\text { soc.-ecol. } \\
\text { context }\end{array}$ \\
\hline & Land cover and land use & 18 & & $\begin{array}{l}\text { Reflected in lad } \\
\text { survey }\end{array}$ & & $\begin{array}{l}\text { Reflected in } \\
\text { land survey }\end{array}$ \\
\hline & Logging & 19 & & & & \\
\hline & $\begin{array}{l}\text { Biophysical factors and } \\
\text { topography }\end{array}$ & 20 & & & & $\begin{array}{l}\text { Reflected in } \\
\text { land survey }\end{array}$ \\
\hline & Historical ties & 21 & & & & \\
\hline
\end{tabular}


TABLE 6.4 Synthesising implementation processes and spatial patterns (cont.)

\begin{tabular}{|c|c|c|c|c|c|}
\hline Key factors & & $\begin{array}{l}\text { Marginal } \\
\text { people }\end{array}$ & $\begin{array}{l}\text { Marginal } \\
\text { governance }\end{array}$ & $\begin{array}{l}\text { Marginal } \\
\text { investment }\end{array}$ & Marginal land \\
\hline $\begin{array}{l}\text { Capability and assets of } \\
\text { villagers }\end{array}$ & 22 & & $\begin{array}{l}\text { Indications of } \\
\text { needs } \\
\text { expressed }\end{array}$ & $\begin{array}{l}\text { Strong } \\
\text { negotiation } \\
\text { power }\end{array}$ & $\begin{array}{l}\text { Strong } \\
\text { negotiation } \\
\text { power }\end{array}$ \\
\hline Accessibility & 23 & & & & \\
\hline Land allocation & 24 & $\begin{array}{l}\text { Fast, majority of } \\
\text { concession } \\
\text { allocated }\end{array}$ & $\begin{array}{l}\text { Parts of } \\
\text { concession, } \\
\text { slow, change of } \\
\text { location }\end{array}$ & $\begin{array}{l}\text { Slow, } \\
\text { fragmented, } \\
\text { small share of }\end{array}$ & $\begin{array}{l}\text { Slow, } \\
\text { fragmented }\end{array}$ \\
\hline
\end{tabular}

Note: The table lists the key factors of our four archetypes and existing spatio-temporal data sets that capture these key factors. Shaded rows indicate key factors for which statistical and spatial data are readily available.

SOURCE: AUTHORS.

Land Allocation (KF 24) were made publicly accessible and were more exhaustive, they could serve as excellent proxies for the type of implementation process. Furthermore, existing LSLA monitoring systems could additionally incorporate indicators such as the role of provincial or district authorities in the implementation process, the way Land Surveys (KF 16) were implemented, and the Capabilities and Assets of Villagers (KF 22). Finally, refining methods to understand who and what define the availability of land would represent a breakthrough for understanding the processes of land allocation.

\section{$5 \quad$ Conclusions}

The research we have described is intended to help overcome certain persistent difficulties of providing adequate, robust evidence on LSLAs for the purpose of decision-making and policymaking, specifically in Laos and Cambodia. Much of this difficulty stems from the existing gap between case study researchwhich typically provides qualitative and process-based insights—and national or global inventories that typically provide place-based (spatially referenced) and quantitative analyses of broader patterns. Using a meta-analysis of case studies that focuses on recurrent interactions between selected key factors, we defined four archetypes of implementation processes. We argue that this type 
of generalisation not only provides insights for land-related policies, but also represents a precondition for linking process-based insights with spatial patterns emerging from place-based studies.

Methodologically, we conclude that both approaches generate valuable yet incomplete evidence for policymaking. Spatial patterns mask important differentiations and do not enable causal understanding. At the same time, a working typology of LSLA implementation processes such as ours is difficult to assess in terms of its validity for higher levels of policymaking and scaling up to different contexts. Finding ways of linking these two perspectives remains a crucial task. At present, there is a dearth of available indicators serving both perspectives, making it difficult to properly link them. Yet, the solution is clearly within reach: inventories of land acquisitions could make these kinds of indicators available with little extra effort. They would need to document how the size and contiguity of a land deal changes over time from the granting of concessions to the final allocation of land. Additionally, information on the use and form of land surveys as well as the time and type of involvement of different actors represents an important proxy for implementation processes.

We believe that this type of combined approach is capable of generating important evidence to inform policy. It enables a better understanding of the overall dimensions and relevance of LSLAS in agrarian transitions. Our own quantitative results point to a highly advanced stage of LSLA proliferation in South-East Asia, necessitating new policies capable of addressing conflicts, impacts on pre-existing land use and natural resources, threatened livelihoods, and outmigration, which could all drive new waves of poverty. At the same time, our analysis of implementation processes clearly shows that there is little space for participatory forms of agricultural investment when large and powerful companies initially arrive on the scene in a new region and are essentially given a pass by senior government authorities. For a long time, the prevailing processes of land allocation in Laos and Cambodia were top-down and authoritarian, further marginalising vulnerable populations. Only now, as land has become scarcer and competition between investors has increased, are new, more inclusive implementation processes emerging. These implementation processes enable various stakeholders to agree on what land is truly underused or 'marginal', and thus ripe for investment. In terms of future land policies, this suggests a role for spatially differentiated moratoria on land concessions. In other words, policymakers could ban concessions in certain areas and allow them in others, encouraging competition between investors and negotiation with local land areas in certain places, while keeping other places free of land concessions to protect vulnerable smallholders. 


\section{References}

Anseeuw, W., M. Boche, T. Breu, M. Giger, J. Lay, P. Messerli and K. Nolte (2012) Transnational Land Deals for Agriculture in the Global South: Analytical Report Based on the Land Matrix Database (Bern, Montpellier and Hamburg: CDE-CIRAD-GIGA), http://publications.cirad.fr/une_notice.php?dk=564980 (accessed on 16 March 2015).

Arino, O. (2010) GlobCover 2009, http://epic.awi.de/31046/1/Arino_et_al_GlobCover 2009-a.pdf (accessed on 16 March 2015).

Borras Jr., S.M., D. Fig and S.M. Suárez (2011) 'The Politics of Agrofuels and Mega-Land and Water Deals: Insights from the ProCana Case, Mozambique', Review of African Political Economy, 38(128), pp. 215-234, DOI: 10.1080/03056244.2011.582758.

Cotula, L. (2012) 'The International Political Economy of the Global Land Rush: A Critical Appraisal of Trends, Scale, Geography and Drivers', Journal of Peasant Studies, 39(3-4), pp. 649-680, Dor: 10.1080/03066150.2012.674940.

Cotula, L., S. Vermeulen, R. Leonard and J. Keeley (2009) Land Grab Or Development Opportunity? Agricultural Investment and International Land Deals in Africa (London and Rome: IIED-FAO-IFAD).

De Koninck, R. (2004) 'The Challenges of the Agrarian Transition in Southeast Asia', Labour Capital and Society, 37(1-2), pp. 285-288, http://lcs-tcs.com/ PDFs/37_12/15-de\%20Koninck.pdf (accessed on 26 May 2015).

Deininger, K. and D. Byerlee (2011) Rising Global Interest in Farmland: Can It Yield Sustainable and Equitable Benefits? (Washington, D.c.: World Bank-International Bank for Reconstruction and Development), http://siteresources.worldbank.org/ DEC/Resources/Rising-Global-Interest-in-Farmland.pdf (accessed on 14 April 2015).

Dwyer, M.B. (2013) 'Building the Politics Machine: Tools for "Resolving" the Global Land Grab', Development and Change, 44(2), pp. 309-333, DOI: 10.1111/dech.12014.

Edelman, M. (2013) 'Messy Hectares: Questions about the Epistemology of Land Grabbing Data', Journal of Peasant Studies, 40(3), pp. 485-501, DOI: 10.1080/ 03066150.2013.801340.

Epprecht, M., N. Minot, R. Dewina, P. Messerli and A. Heinimann (2008) The Geography of Poverty and Inequality in the Lao PDR (Bern: Geographica Bernensia).

Friis, C. and A. Reenberg (2010) Land Grab in Africa. Emerging Land System Drivers in a Teleconnected World (Copenhagen: Global Land Project International Project Office), http://www.ihdp.unu.edu/docs/Publications/GLP/GLP_report_o1.pdf (accessed on 26 May 2015).

GoL (Government of Lao People's Democratic Republic) (2008) Decree On the Implementation of the Land Law, No. 88/PM, 3 June, Ventiane, http://www .prflaos.org/sites/default/files/policy/40.\%2oPM\%2oDecree\%2oon\%2othe\%20 Implementation\%20of\%2othe\%2oLand\%2oLaw.pdf (accessed on 16 March 2015). 
Görgen, M., B. Rudloff, J. Simons, A. Üllenberg, S. Väth and L. Wimmer (2009) Foreign Direct Investment (FDI) in Land in Developing Countries (Eschborn: Deutsche Gesellschaft für Technische Zusammenarbeit, GTz), http://www.giz.de/expertise/ downloads/Fachexpertise/giz2010-en-foreign-direct-investment-dc.pdf (accessed on 26 May 2015).

Kingdom of Cambodia (2012) Identification of Poor Households Programme, http:// www.idpoor.gov.kh/en/home (accessed on 16 March 2015).

Lambin, E.F. and H.J. Geist (eds.) (2006) Land-Use and Land-Cover Change. Local Processes and Global Impacts (Berlin: Springer).

Land Matrix Partnership (2014) Land Matrix Newsletter, January 2014, http://www .landmatrix.org/media/filer_public/b2/48/b24869d1-ffi7-4cb2-8bc3-5c55ef6a3eoc/ lm_newsletter_3-4.pdf (accessed on 20 April 2015).

LICADHo (Cambodian League for the Defense of Human Rights) (2013) The Great Cambodian Giveaway: Vizualizing Land Concessions over Time, http://www.licadhocambodia.org/concession_timelapse/ (accessed on 16 March 2015).

Messerli, P. (2000) 'Use of Sensitivity Analysis to Evaluate Key Factors for Improving Slash-and-Burn Cultivation Systems on the Eastern Escarpment of Madagascar', Mountain Research and Development, 20(1), pp. 32-41, DOI: 10.1659/0276-4741(2000)020[0032:UOSATE]2.0.CO;2.

Messerli, P., M. Giger, M.B. Dwyer, T. Breu and S. Eckert (2014) 'The Geography of Large-Scale Land Acquisitions: Analysing Socio-Ecological Patterns of Target Contexts in the Global South', Applied Geography, 53, pp. 449-459, DOI: 10.1016/ j.apgeog.2014.07.005.

Messerli, P., A. Heinimann, M. Epprecht, S. Phonesaly, C. Thiraka and N. Minot (eds.) (2008) Socio-Economic Atlas of the Lao PDR-An Analysis Based on the 2005 Population and Housing Census (Bern: Geographica Bernensia).

Messerli, P., A. Heinimann, M. Giger, T. Breu and O. Schönweger (2013) 'From "Land Grabbing" to Sustainable Investments in Land: Potential Contributions by Land Change Science', Current Opinion in Environmental Sustainability, 5, pp. 528-534, DOI: 10.1016/j.cosust.2013.03.004.

Michel, L. (2013) Key Factors Influencing Decision-Making on Large-Scale Land Acquisitions in Cambodia, unpublished Msc Thesis (Bern: University of Bern), http://www.cde.unibe.ch/v1/CDE/pdf/MSc\%2oThesis\%2oLukas\%2oMichel.pdf (accessed on 16 March 2015).

Ministry of Agriculture, Forestry and Fisheries of Cambodia (2012) http://www.maff .gov.kh/ (accessed on 16 March 2015).

Nalepa, R.A. and D.M. Bauer (2012) 'Marginal Lands: the Role of Remote Sensing in Constructing Landscapes for Agrofuel Development', Journal of Peasant Studies, 39(2), pp. 403-422, DOI: 10.1080/03066150.2012.665890. 
NAoL (National Assembly of Lao People's Democratic Republic) (2004) Law on the Promotion of Foreign Investment, No. 11/NA, 22 October, Vientiane, http:// www.ilo.org/dyn/natlex/natlex_browse.details?p_lang=en\&p_country=LAO\&p_ classification $=01 \&$ p_origin=SUBJECT (accessed on 16 March 2015).

NCCD (National Committee for Sub-National Democratic Development) (2012) Commune Council Database, http://db.ncdd.gov.kh/ccd/home/index.castle (accessed on 16 March 2015).

NGO Forum (2012) http://www.ngoforum.org.kh/ (accessed on 16 March 2015).

oDC (Open Development Cambodia) (2013) http://www.opendevelopmentcambodia .net/ (accessed on 16 March 2015).

Oya, C. (2013) 'Methodological Reflections on "Land Grab" Databases and the "Land Grab" Literature "Rush", Journal of Peasant Studies, 40(3), pp. 503-520, DoI: 10.1080/03066150.2013.799465.

RGC (Royal Government of Cambodia) (2005) Sub-Decree on Economic Land Concession, Sub-Decree No. 146, 27 December, Phnom Penh, http://www.cambodia investment.gov.kh/sub-decree-146-on-economic-land-concessions_051227.html (accessed on 16 March 2015).

Rigg, J. (2006) 'Land, Farming, Livelihoods, and Poverty: Rethinking the Links in the Rural South', World Development, 34(1), pp. 180-202, DOI: 10.1016/ j.worlddev.2005.07.015.

(2005) Living in Transition in Laos: Market Integration in Southeast Asia (London: Routledge).

Schönweger, O., A. Heinimann, M. Epprecht, J. Lu and P. Thalongsengchanh (2012) Concessions and Leases in the Lao PDR: Taking Stock of Land Investments (Bern: Geographica Bernensia).

Scoones, I., R. Hall, S.M. Borras Jr., B. White and W. Wolford (2013) 'The Politics of Evidence: Methodologies for Understanding the Global Land Rush', Journal of Peasant Studies, 40(3), pp. 469-483, DoI: 10.1080/03066150.2013.801341.

Sommer, L. (2013) Deciding on Large-Scale Land Acquisitions in the Lao PDR: Case Studies on Land Concessions in the Agroforestry Subsectors from Central Laos, unpublished Msc Thesis (Bern: University of Bern), http://www.cde.unibe.ch/vi/CDE/pdf/ MSc\%2oThesis\%2oLaura\%20Sommer_15\%2001\%202014.pdf (accessed on 16 March 2015).

Üllenberg, A. (2009) Foreign Direct Investment (FDI) in Land in Madagascar (Eschborn: GTZ).

Vester, F. and A.V. Hesler (1987) Sensitivitätsmodell (Frankfurt: Umlandverband).

Wiesmann, U., C. Ott, C. Ifejika Speranza, U. Müller-Boeker, P. Messerli and J. Zinstag (2011) An Actor's Model as Conceptual Orientation in Research for Sustainable Development (Bern: Geographica Bernensia), http://www.north-south.ch/publications/ Infosystem/On-line\%20Dokumente/Upload/11_Wiesmann\%281\%29.pdf (accessed on 20 April 2015). 
Zurflueh, J. (2013) Vietnamese Rubber Investments in the South of the Lao PDR: Key Factors Influencing Decision Making in Large-scale Land Acquisitions by Vietnamese Investors in the Agro-forestry Sector of the Lao PDR, unpublished MSc Thesis (Bern: University of Bern), http://www.cde.unibe.ch/Pages/Publication/2499/Default .aspx (accessed on 16 March 2015). 